\title{
Yearning for the Lost Paradise: The "Great Unity" (datong) and its Philosophical Interpretations
}

\author{
Bart DESSEIN*
}

\begin{abstract}
In the course of China's history, the term datong (great unity) has been interpreted in multiple ways. This article first discusses the concept as understood in the Liji, and then focuses on the way in which the perceived loss of the "great unity" within "all-under-heaven" (tianxia) at the end of the Qing dynasty (1644-1911), and the endeavor to reconstruct the empire as a modern nation-state starting in the early twentieth century, informed the way the term datong was interpreted. After discussing the interpretations by Wang Tao (1828-1897), Hong Xiuquan (1813-1864), Kang Youwei (1858-1927), Liang Qichao (1873-1929), Sun Zhongshan (1866-1925), and Mao Zedong (1893-1976), this work concludes with a discussion on how, against the background of the perceived threat of loss of national unity that characterizes the contemporary People's Republic of China, a New Confucian interpretation is developed.
\end{abstract}

Keywords:Datong,Moism, Confucianism,New Confucianism, Nationalism, Communism

Hrepenenje po izgubljenem raju: "Vélika enotnost" (datong) in njene filozofske interpretacije

\section{Izvleček}

V teku kitajske zgodovine je bil termin datong (vélika enotnost) interpretiran na najrazličnejše načine. Clanek najprej obravnava razumevanje tega koncepta znotraj klasičnega dela Knjige obredov ( $\mathrm{Li}$ ji), potem pa se osredotoči na opis izgube »vélike enotnosti« znotraj koncepta "vse pod nebom" (tianxia), kakršen se je oblikoval na koncu dinastije Qing (1644-1911). Ta interpretacija termina datong je bila izdelana v sklopu prizadevanj za rekonstrukcijo kitajskega cesarstva kot moderne nacionalne države, ki so prevladovala na Kitajskem v zgodnjem dvajsetem stoletju. V tem okviru članek najprej obdela interpretacije Wanga Taoja (1828-1897), Honga Xiuquana (1813-1864), Kanga Youweija (1858-1927), Lianga Qichaota (1873-1929), Suna Zhongshana (1866-1925) ter Maota Zedonga (1893-1976), nato pa na osnovi izgube nacionalne enotnosti, kakršna opredeljuje sodobno LR Kitajsko, analizira, na kakšen način se razvijajo nove interpretacije tega pojma v okviru modernega konfucijanstva.

Ključne besede: datong, moizem, konfucijanstvo, moderno konfucijanstvo, nacionalizem, komunizem

* Bart DESSEIN, Professor at the Department of Languages and Cultures, Ghent University, Belgium.

bart.dessein[at]UGent.be

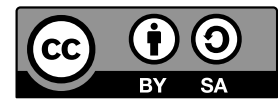




\section{Datong in Imperial China}

The first appearance of the concept of datong in the literature is in the seventh chapter "Liyun" of the Liji (Records of Ritual), a Confucian political handbook that was compiled in the third to second centuries BCE. The "Liyun" chapter devotes 107 of its total of 744 characters to the concept datong. (See Pusey 1983, 34) It may have been, as noted by Joseph Needham $(1958,167-8)$, "a very peculiar historical turn of events that this highly subversive account became embedded in one of the Confucian classics", as passages with the same wording are also found in the Mozi, and thus point to an original Moist affiliation of the concept. ${ }^{1}$ We do know, however, that the Moist philosophy was overshadowed by Confucianism in the Han dynasty, and that, it should be remembered, Han dynasty Confucianism is overall characterized by its eclectic nature. Given the installation of Confucianism as state orthodoxy in the Han dynasty, the mere fact that this passage was taken up in a Confucian compilation was presumably because of its political usefulness for the Han Confucian elite. The 107 characters devoted to the concept datong run as follows:

When the big road of virtue was followed, "all-under-heaven" (tianxia) was public good. Functionaries were selected according to their abilities. Their words were trustworthy, and they cultivated harmony. That is why people did not only treat their own relatives as relatives, did not only treat their own children as children, and made sure that elder people had all they needed until the end of their days, that grown-ups had all they needed, that children had all they needed to grow, that widowers and widows, orphans, and sick ones all had what they needed to sustain themselves. They made sure that men had a job, and women had a place where they belonged. They did not allow the harvest to be left in the field, but neither did they want to hoard it for themselves. They disliked that their power was not made useful for others, but neither did they want to use it for themselves. Therefore, bad plans were not put into practice, there were no robbers, thieves, nor traitors. Therefore, outer doors were not closed. This is what is called datong. (Liji 1988,120)

This passage is immediately followed by the statement that, in the Han dynasty, "the big road of virtue" is hidden, and that "all-under-heaven" therefore belongs to the different clans $(j i a) .{ }^{2}$ (ibid., 121) Having described the actual situation of

1 On the importance of this Moist affiliation for Maoism: see further.

2 According to Chen (2011,3-4), this may be regarded as a reference to dynastic rule, under which the monarch is succeeded by his son and the monarch regards the state as his family possession. 
the Han dynasty that does not conform to what a datong society should be, the "Liyun" chapter continues as follows:

That is why Yu, (Cheng) Tang, (King) Wen, (King) Wu, (King) Cheng and the Duke of Zhou were selected. Of these six gentlemen (junzi), there is none who does not follow the rituals (li). They have manifested their justice $(y i)$, tested their trustworthiness $(x i n)$, revealed those who had made mistakes, executed benevolence (ren), made (people) give way to each other, and have instructed the people to constantly do so. Those who did not do so were chased away by those having power and position, and they were regarded as unfortunate by the masses of the people. (Then came) what is said to be xiaokang. (ibid.)

It is thus clear that it was in the absence of a datong society that six Confucian worthies were selected. These should at least uphold a xiaokang society which, as can be deduced from the "Liyun" chapter, is inferior to the datong society. (See Chen 2011 , 2) Such a "second best" society manifests itself through governance by different clans. It is therefore also important to note that while the (originally Moist) concept of datong appears in the Liji, that of xiaokang appears significantly earlier: it first appears in the Shijing (Classic of Poetry), the content of which dates back to the tenth century BCE. The xiaokang society is therefore not only inferior to the datong society, but the concept appears earlier in Chinese thought. Phrased differently: achieving a datong society is a matter of historical progress and ascent, and historical development is such that the present xiaokang society can and has to be transformed into a datong society. In the ode "Min lao" (The People Are Hard Pressed) of the "Daya" part of the Shijing (Part III, Book II, 9), we read:

The people indeed are heavily burdened,

But perhaps a little ease (xiaokang) may be got for them.

Let us cherish this centre of the kingdom,

To secure the repose of the four quarters of it.

Let us give no indulgence to the wily and obsequious,

In order to make the unconscientious careful,

And to repress robbers and oppressors,

Who have no fear of the clear will (of Heaven).

Then let us show kindness to those who are distant,

Contrary to this actual situation, a datong society is characterized by the selection of functionaries based on merit. Such functionaries are supposed to act for the "common good". 
And help those who are near; -

Thus establishing (the throne of) our king. ${ }^{3}$

This ode shows a clear political message: (1) the masses resort to a moral leadership ("cherish this centre of the kingdom") that will (2) guide them to a peaceful era of social redistribution ("a little ease may be got for them"); this is (3) the conduct to be followed both for the homeland and internationally ("show kindness to those who are distant, and help those who are near"); and (4) this conduct will be a model for the world at large ("establishing the throne of our king"). In the latter respect, the message of the xiaokang (and of the datong) society is related to another concept that prevails in the Liji: the Confucian concept of daxue.

\section{The Liji and the Political Mission of the Chinese Confucian State}

Commenting on the "Daxue" ("The Great Learning"), the 39th chapter of the Liji, Wing-tsit Chan $(1963,84)$ says the following:

The importance of this little classic is far greater than its small size would suggest. It gives the Confucian educational, moral, and political programs in a nutshell, neatly summed up in the so-called "three items": manifesting the clear character of man, loving the people and abiding in the highest good; and in the "eight steps": the investigation of things, extension of knowledge, sincerity of the will, rectification of the mind, cultivation of the personal life, regulation of the family, national order, and world peace.

For the present discussion the last two steps-national order and world peaceare important. On this issue, the original text has the following to say (translation by Wing-tsit Chan 1963, 86-87):

The ancients who wished to manifest their clear character to the world would first bring order to their states. Those who wished to bring order to their states would first regulate their families. Those who wished to regulate their families would first cultivate their personal lives. Those who wished to cultivate their personal lives would first rectify their minds. Those who wished to rectify their minds would first make their wills sincere. Those who wished to make their wills sincere would first extend their knowledge. The extension of knowledge consists in the investigation of things. When things are investigated, knowledge is extended; when knowledge

3 Translation Legge 1970, 495. Italics mine (B.D.). 
is extended, the will becomes sincere; when the will is sincere, the mind is rectified; when the mind is rectified, the personal life is cultivated; when the personal life is cultivated, the family will be regulated; when the family is regulated, the state will be in order; and when the state is in order, there will be peace throughout the world. ${ }^{4}$ (Zhu 1988, 1)

Confucianism was the state doctrine throughout China's imperial history; however, necessitated by concrete historical events and developments, this passage has continuously been reinterpreted--as is the whole of Confucianism. One such major development has been the formulation of Neo-Confucianism (in China itself referred to as daoxue — the study of the dao): a merging of certain Daoist and Buddhist elements with the Confucian doctrine starting from the Sui dynasty (581/589-618). This Neo-Confucianism came to full maturation in the Song dynasty (960-1279), when Zhu Xi (1130-1200) formulated his lixue (the study of the principle) interpretation of Confucianism. I will return to the importance of Zhu Xi's interpretation later on. Suffice here to quote his interpretation of the "Daxue" passage given above (translation by Wing-tsit Chan 1963, 91-92):

What is meant by saying that in order to govern the state it is necessary to regulate the family is this: There is no one who cannot teach his own family and yet teach others. Therefore the superior man (ruler) without going beyond his family, can bring education into completion in the whole state. Filial piety is that with which one serves his ruler. Brotherly respect is that with which one serves his elders, and deep love is that with which one treats the multitude. (...) When the individual families have become bumane, then the whole country will be aroused toward bumanity. When the individual families have become compliant, then the whole country will be aroused toward compliance. (...) Therefore the superior man must have the good qualities in himself before he may require them in other people. (...) Therefore the order of the state depends on the regulation of the family. (...) Only when one has rightly ordered his household can he teach the people of the country. (...) Because he served as a worthy example as a father, son, elder brother, and younger brother, therefore the people imitated him. This is what is meant by saying that the order of the state depends on the regulation of the family. ${ }^{5}$ (Zhu 1988, 1)

\footnotetext{
$4 \quad$ Italics mine (B.D.).

5 Italics mine (B.D.).
} 
A ruler is thus presented as having the task of cultivating himself according to Confucian moral principles in order to influence his state and the world at large (tianxia). Fei Xiaotong $(1992,62-63)$ illustrated the political view that is expressed in the "Daxue" with the metaphor of the concentric circles that appear when throwing a rock into the water. For an individual, the concentric circles of his individual moral and social behaviour are the product of his potential moral autonomy. When an individual develops his moral potentiality, he can increase his impact on other individuals and, hence, his value in society. Society is thus both the inspiration and the aim of an individual's existence, and the value of an individual is measured by his value for society. (Fei 1992, 67) ${ }^{6}$ This interpretation also reveals the "international" politico-religious mission Confucianism attributed to the "Son of Heaven" (tianzi) and to the "Middle Kingdom" (Zhongguo). In the same way as each individual is at the centre of the circles produced by his or her own social influence, also each state is at the centre of the concentric circles of its moral and political influence. The morality of a state expands to the world at large, to "all-under-heaven" (tianxia). Applied to international relations, this viewpoint was traditionally interpreted as indicating that when the ruler, the "Son of Heaven", successfully safeguards the harmonious relations in his state through his exemplary Confucian behaviour, this influence would extend to the neighbouring territories, with China, the "Middle Kingdom" at the centre. ${ }^{7}$ In line with the Confucian philosopher Dong Zhongshu's (179?-104? BCE) famous view of interpersonal relations, the relation between Zhongguo and the bordering regions was interpreted as the relation between an older and younger brother, in which China is the older brother and the non-Chinese territories, the so-called tribute states, are the younger brothers. As in a family, the older brother sets the moral example for the younger, and the younger brother follows this example. As with individual relations, "all-under-heaven" is both the inspiration and the aim of China's existence. (See Fairbank and Teng 1941, 129-30) In periods in which the cultural lustre of the Chinese Confucian elite in the capital was waning, the "cultural model" based on moral virtue no longer worked. As a result, the Chinese political elite could no longer maintain its cultural authority over the bordering territories, while the "tribute states" no longer had a political, economic or cultural profit in maintaining their relations with China. The more recent and less thorough the connection with China had been, the easier Chinese culture disappeared again.

$6 \quad$ Also see Shun 2004, 190-3; and Schwartz 1985, 113.

7 Schmidt-Glintzer $(2009,179)$ remarks that already in the "Yu gong" chapter of the Shanhai jing (Classic of Mountains and Seas), the world is represented as consisting of five concentric zones: the royal domain, the domains of the princes, the pacification zone, the zone of allied barbarians, and the zone of savagery. For a historical assessment of the international aspect of this Confucian concept: see Dessein 2016; also see Hellendorff 2014. 
(ibid.) It can therefore be argued that Chinese history is a continuous movement of slowly surging and retreating concentric circles of Han cultural influence.

We can thus conclude that the occurrence of both the concepts datong and xiaokang in the Confucian Liji, and its inherent relation to the concept daxue as explained in the same work, reveal the Confucian conviction that the perfect datong society has been long since lost, but that it is the task of a Confucian ruler to, for the time being, at least maintain a xiaokang society, in order to eventually be able to restore the datong order. Phrased differently, after an initial decline, progress towards a better (utopian) society is possible. Such a society will then be an example for the world at large. ${ }^{8}$

\section{Datong in the Transition Period from the Empire to the People's Republic of China}

When in the confrontation with Europe's military dominance in the middle of the nineteenth century, scholars such as Wei Yuan (1794-1857) claimed that there was no Western knowledge worth studying, except for military technology and knowledge about weaponry, and thus it would be sufficient for China to master these two areas in order to be able to defend itself against the West, this revealed the conviction that Confucianism still had great value for its connection to national unity. (See Wei 1852) This conviction also remained visible in the "Self Strengthening Movement" (ziqiang yundong) of the 1860s_an attempt to make China materially so strong that it would be better able to defend itself against the West.

Contrary to Wei Yuan, Wang Tao (1828-1897) had travelled to Europe and had discerned a peculiar cultural tradition there. He therefore claimed that it was necessary to study European culture in order to become acquainted with the basis of its superior technology. According to him, the knowledge and use of Western technology would, in practice, lead Chinese (Confucian) culture as essence $(t i)$ to embrace Western technology as function (yong). ${ }^{9}$ The final outcome of this would, so he claimed, be that the different national histories would fuse into an era of universal peace (taiping) in which the world would become one "great unity"

8 Pusey $(1983,34)$ remarks: "In Confucius's mind at least, the Ta t'ung was a Golden Age of the past, and there is no real promise given that it will be attained again".

9 It is with Zhang Zhidong's (1837-1909) Quan xue pian (Exhortation to Study), published in 1898, that the focus in "zhong ti xi yong" shifted from the original "Western function", meaning that Western technology had to be introduced in China, to the neo-conservative "China as essence", meaning that the Chinese tradition had to be preserved at all costs (see Li 1995). 
(datong). ${ }^{10}$ Notwithstanding the fact that, with Wang Tao, the term datong attains a clear international dimension, the equation of the "essence" with China at the same time echoes the age-old Confucian claim that in this unified world the right to rule "all-under-heaven" would remain a Confucian prerogative - an idea that is now being revived in New Confucian thinking.

In his political theory, Wang Tao also relied heavily on the traditional belief in the three-ages (san shi) theory that is discussed in the commentaries to the Confucian Gongyang zhuan, itself a Han dynasty commentary on the Chunqiu (Spring and Autumn Annals). The Gongyang zhuan belongs to the New Text School of Confucianism, the same Confucian school to which the above mentioned Dong Zhongshu belonged, and presents a holistic view of the universe in which heaven, earth and man are interconnected. ${ }^{11}$ According to the three-ages theory, human history goes through the stages of the age of disorder (juluan) and the age of ascending peace (shengping), in order to finally reach the age of universal peace (taiping). (See Wang 2001, 42) (2 $^{12}$

Chinese society in the middle of the nineteenth century was far removed from the "utopian" datong and taiping: dynastic decline combined with the incursions of Western powers had impoverished China and its population. It is against this background, and inspired by Western ideologies that were introduced in China, that the Hakka Hong Xiuquan (1813-1864) shaped his Taiping ideology. Hong Xiuquan's "utopian" society, his "Heavenly State of Great Peace" (Taiping tianguo) was to be one in which men and women were equal, private property was abolished, and land and wealth were redistributed - the latter reminiscent of the description of xiaokang in the Shijing. ${ }^{13}$ Given his Christian inspiration-he identified himself as the younger brother of Jesus-he claimed that this "brotherhood of men" would be shaped under the supreme deity. ${ }^{14}$ (See Kuhn 1978, 277) Notwithstanding his revolutionary stance of gender equality and his naive interpretation of socialism, Hong Xiuquan, in his Taiping zhao shu (The Taiping Proclamation) quoted at length the passage of the Confucian Liji in which the datong society is mentioned: "In the days when the big road (of virtue) was practiced, (...)

10 For an evaluation of the Fairbankian interpretation of China's modernization process from first understanding only the superiority of Western weapons, then grasping that of Western institutions, and finally appreciating Western values (see Metzger 2012, 238).

11 Note that the Gongyang zhuan is also important in some New Confucian theories, such as in the one presented in Jiang Qing's "Constitutional Confucianism" (see Jiang 2013).

12 Wang Tao's speculation on the future of history is seen in his "Yuan dao" (Explanation of the Dao).

13 On Hong Xiuquan see Kuhn (1978, 266-74).

14 Bauer $(1974,407)$ remarks that datong had for thousands of years been the "paradise" of religious Confucianism. 
men treated all other men as their own kin". A "socialist" interpretation of datong would, along with Christian elements and the concept of an apocalyptic revolution, never cease to interact throughout the following century. ${ }^{15}$ (See Goossaert and Palmer 2011,39)

Probably the most influential interpretation of datong was the one Kang Youwei (1858-1927) formulated in his Datong shu (Book on the Great Unity). A first draft of this work, which both Kang Youwei and Wang Tao had previously attempted, and was based on the commentaries to the Gongyang zhuan, was written in 1885 . The work was completed in 1902 and posthumously published in $1935 .{ }^{16}$ (Chen 2011, 5) The Datong shu, as James Reeve Pusey $(1983,18)$ describes it, was "a plan for world unity and an end to war, but more than that it was a plan for an ideal world society through which man could virtually conquer evil". Conquering evil-i.e., suffering — was thus sought in this world. (Pusey 1983, 19) As in Hong Xiuquan's utopian society, and also in the datong society, social inequality would be extinguished. ${ }^{17}$ (Chen 2011, 6-7). Reminiscent of what Hong Xiuquan had claimed before him, and important also for later Maoism, is that Kang Youwei stated the following:

In the world of the "great unity" (datong) there will be no differences between classes or races. There will be no inferior people, or religious leaders. Everyone will be equal and all under Heaven will possess equal rights. In the world of the "great unity", the boundaries between families and the sexes will disappear. Marriage will be based on liberty. (Kang in Liu 2002, 716)

The abolishment of classes can be interpreted as a reference to the evil situation mentioned in the Liji that "all-under-heaven" is ruled by the different clans ( $j i a$ ). Kang Youwei shared this opinion with the adherents of so-called early twentieth century "radical Confucianism" (junxue) according to whom the installment of Confucianism as state orthodoxy had led to a situation in which such rule

15 For the CCP's explicit claim of filiation to the Taiping movement see Cohen (1997,292-3). Notice also the Christian influence in Jiang Qing's "Constitutional Confucianism”. For the latter see Bai $2013,118$.

16 The first manuscript of this Datong shu was entitled Renlei gongli (The Principle of the Common for Mankind) (see Bauer 1974, 417).

17 Goossaert and Palmer $(2011,95)$ remark that "Groups such as the Wanguo dadehui and the Daode xueshe maintained a strong Confucian identity, to which they added, however, a universalist tendency, honoring the founders of all major religions and advocating the realization, on a global scale, of the "Great Commonwealth" (datong) dreamed of in the Book of Rites and elaborated on in the utopian mode by Kang Youwei and others". 
was only concerned with maintaining power in the hands of the ruling elite, and was no longer interested in serving the "common good". (See Dessein, forthcoming) Kang Youwei thus adhered to the xiaokang ideal that political and social institutions should serve to relieve the hardships of the common people. ${ }^{18}$ As such, he advocated abolishing nine boundaries in order to create a datong society: nation-boundaries, class-boundaries, race-boundaries, sex-boundaries, family-boundaries, occupation-boundaries, disorder-boundaries (i.e. the fact that there are unequal laws), kind-boundaries (i.e., the difference between men, birds, mammals, insects and fish), and suffering boundaries (i.e. the fact that suffering produces further suffering without end). (Kang 1936, 78) ${ }^{19}$ Lifting these boundaries was possible precisely because of man's innate ren (humaneness), an idea he shared with Mengzi. ${ }^{20}$ (See Kang 1968, 376) According to Kang Youwei, with society's ascent in history the Confucian ren would increase accordingly, with the supreme ren eventually coinciding with the datong society.

Reminiscent of the spirit that emanates from the chapter "Daxue" of the Liji, Kang Youwei interpreted the aforementioned three-ages theory in a way that predicts China's eventual "revenge": China's age of petty selfishness was now, as an outcome of this first stage, in an age of resistance to the Western barbarians, and would, in the end, be triumphant as the "inspiring genius of One World, to which all barbarians would voluntary flock in peace". ${ }^{21}$ (Pusey 1983, 30) The "Middle Kingdom" would thus return to its historical position as the hub of datong (ibid., 35). Referring to the Confucian classics, Kang Youwei could thus claim that, according to Confucianism, history was a progressive process that would eventually lead to perfect happiness. That this interpretation of history was not in the Gongyang zhuan, which was already eclectic in nature, but instead only in a commentary to the commentary to the Chunqiu written by He Xiu (129-182) in the Later Han dynasty must, for Kang Youwei, only have been a minor detail in his blueprint to attain "utopia". 22

The progress Kang Youwei envisaged was not Darwinian - a trait that would characterize the philosophy of Sun Zhongshan (1866-1925) — but was based on

18 See the passage of the "Min lao" quoted above.

19 See also Bauer 1974, 418; Rošker 2008, 121-2.

20 Notice also the focus on the Mencian ren in contemporary Taiwanese New Confucianism.

21 For Kang Youwei's comment on the three-ages theory: see Bauer 1974, 415-6. See also the maxim "one people one dream" of the 2008 Beijing Olympics.

22 Pusey $(1983,31)$ remarks that "K'ang Yu-wei saw in the similarities between the commentaries of Tung Chung-shu and Ho Hsiu proof of a legitimate oral tradition, handed down in almost secret 'apostolic succession' from Confucius himself, and he could thus accept their commentaries as faithful transmission of Confucius's true teachings". 
reason. It is very likely that Kang Youwei felt his idea of reasoned progress was supported through works such as the 1873 translation of Lyell's Elements of Geology, and the 1887 translation of William and Robert Chambers' Homely Words to Aid Governance, a work of which the title resembles the Confucian Zi zhi tong jian (Universal Mirror as Aid in Governance). (ibid., 23, 26) The Chambers' book saw progress as civilization, and civilization as the gradual extension of reason, knowledge, and good will.

A last element that indicates how Kang Youwei, although convinced of the value of technology and reason, still remained trapped in China's Confucian past, is that he advocated redefining Confucianism within the new "religious" paradigm that was introduced with the introduction and gradual popularity of Christianity in nineteenth century China. As Christianity became defined as a religion (zongjiao) and traditional Chinese belief systems, including Confucianism, were degraded as superstition (mixin), Kang Youwei tried to "save" Confucianism by redefining it as a "religion" in its own right. In order to transform Confucianism into a "national religion" (guojiao) — and the only possible one, for that matter-he proposed banning all religious institutions and transforming the Confucian temples that had begun to be confiscated from 1901 on into schools for instruction in what he called "Kongjiao", the Confucian religion. (See Goossaert and Palmer 2011, 45-47) A "modernized" Confucianism would thus have to become the Chinese "orthodox religion", in the same way as an "orthodox" Christianity was perceived as "orthodox religion" in many modern nineteenth century European countries. ${ }^{23}$ Reshaping Confucianism as a national religion may have meant that elements of local cults that had traditionally been integrated in "State Confucianism" would now have to be avoided, thus completely severing local cults from the realm of official "religion". (See Goossaert and Palmer 2011, 55-56) On the other hand, it would also mean that Confucianism would no longer be a dividing factor between the elite and common people, but that Confucius would become a symbol for all and be honoured by all in the nation-state- a guojiao indeed. (See Kuo 2008,67) Such a "national religion" could obviously be used as an instrument to attain a Confucian unified datong nation-state.

After Liang Qichao (1873-1929) had highly praised Kang Youwei's political insights, claiming that "my teacher's philosophy is socialist philosophy", ${ }^{24}$ Sun

23 This shows that Kang Youwei was not so much driven by "intellectual rationality" as by an inspiration to modernize tradition (see Goossaert and Palmer 2011, 52).

24 Pusey $(1983,357)$ notes that the first time Liang Qichao ever mentioned socialism was in his biography of Kang Youwei, published in the December 21, 1901 issue of the Qingyi bao, and that "he awarded it his ultimate compliment by insisting that 'my teacher's philosophy is socialist philosophy" and that he "had come upon much the same ideal thanks to the inspiration of the 'Li yun's ta t'ung"'. 
Zhongshan connected the datong concept to the Three People's Principals, in the sense that the purpose of the Three People's Principles was to bring about datong. (Chen 2011, 4; Zhang 1988, 6) ${ }^{25}$ This can still be seen in the Republic of China's "national" anthem, originally a Kuomintang party song, which puts it as follows: "The Three People's Principles shall be our guiding faith, to build the Republic and advance to the datong". With Confucianism dismissed as vehicle to rally the collective feelings of all people, Sun Zhongshan brought in the Nationalist Party (Guomindang) and the concept dangguo (party state) - nationalist feelings for the state were identified with the Nationalist Party that came to be regarded as the incarnation of the new state. ${ }^{26}$ (See Harrison 2001, 190-3) According to Sun Zhongshan, it was necessary to first deconstruct the Chinese "cultural state" in order to create the Chinese "nation-state". In his inaugural speech on the first congress of the Nationalist Party in January 1912, he therefore declared that he no longer wanted to "govern" the state through the Party (yi dang zhi guo), but to "establish" it through the Party (yi dang jian guo). (See Fitzgerald 1996, 185) The only way for the citizens to respond to the nationalist appeal and to contribute to the "establishment of the state" was hence to become members of the Party-much in the same way as they, in imperial times, had to become part of the Confucian bureaucracy. The conviction that a social revolution was impossible without a class struggle aligned Sun Zhongshan with Communism. This is evident from one of his last statements:

When we want to solve the social question in China, then we pursue an aim that is no different from what foreign countries also face: it is the wish that the masses of the people of all countries may reach peace and happiness, and may no longer suffer under the unequal distribution of capital and means of production. When we pursue this aim to liberate them from suffering, we also have to wish for Communism. (...) The idea that is inherent in our "Three People's Principles is that the people should possess and rule (itself) and be happy. (...) This aim is nothing else than the world of 'great unity' that Confucius (once) craved for". (Sun 1960, 271)

The datong ideal was thus put forward as much by constitutional monarchists, such as Kang Youwei, as by republicans such as Sun Zhongshan. Both were convinced that the datong society had to be realized in China first, before it could be realized in "all-under-heaven". (See Pusey 1983, 32)

25 See also Pusey 1983, 32.

26 This move would also prove important for presenting the Chinese Communist Party as an incarnation of the unified (datong) nation-state. See further. 


\section{Datong in the People's Republic of China}

Having been a widely used symbolic concept in the last decades of the empire and the Republic, also China's communist leaders continued to refer to the datong utopia. In the same way as Sun Zhongshan had advocated the Guomindang as an instrument to unify China, Mao Zedong (1893-1976) alluded to the leading role of the $\mathrm{CCP}$ in its historical mission of modernizing the Chinese peasants and workers and uniting them in a communist society when he stated:

China can develop steadily, under the leadership of the working class and the Communist Party, from an agricultural into an industrial country, and from a new-democratic into a socialist and communist society, can abolish classes and realize the "great unity" (datong). ${ }^{27}$ (Mao 1961)

With its mention of the abolishment of classes, this statement can be seen as a development of the earlier statement Kang Youwei had made in his Zhongguo zhexue shi (History of Chinese Philosophy), as noted above. Loyal to his Marxist foundations, Mao Zedong referred to both the Marxist scheme of history in five stages (primitive communism, slavery, feudalism, capitalism, and communism), and to the three-stages scheme of historical development, culminating in the datong society. (See Goossaert and Palmer 2011,171) Marxist historiography was thus brought into the much older Confucian framework of historic development. ${ }^{28}$ (See Pusey 1983, 33, 155-6) This is also evident from Guo Moruo's (1892-1978) Makesi jin wenmiao (Marx visits a Confucian Temple), a text written in 1925. Here, Guo Moruo, a friend of Mao Zedong, places the following statement in the mouth of Confucius in response to Marx's description of the ideal Communist society: "Yes, truly (...) your ideal society and my world of 'great unity' are completely the same without us having deliberated over it. Let me cite a part of an old text of mine for you!" (Guo in Liu 1953), after which Confucius starts to recite the part of the Liji on datong.

27 Notice that the original English text reads "Great Harmony" instead of "great unity". See also Schram 2002, 411-2.

28 Chen $(2014,4-8)$ mentions that when Marxism first arrived to China, it was understood from the perspective of the traditional system of thought that was dominant during that period and thus, inevitably, traditional elements infiltrated the new ideology. For example, the concept of "great unity" (datong) came to represent the ideals of socialism and communism and made it easier for the masses to grasp the concept of "the world belongs to all" (tianxia wei gong), but at the same time, it brought with it the idea that the evolution from socialism to communism was a continuous struggle against private property, ignoring the importance of the development of the productive forces. That the Marxist chronology starts off from the stage of primitive communism may also help to explain Mao Zedong's sympathy for Moism. Mao's revaluation of Moism, further, did not infringe on the fusion of Marxist and Confucian historiography, as the famous originally Moist datong chapter had already been integrated in Confucian philosophy in the Han dynasty. 
The communist ideology also fused with the age-old Confucian "international" dimension. This is clear from Zhou Enlai's (1898-1976) statement that "Socialist patriotism is not a narrow nationalism, but a patriotism aimed to strengthen national pride under the guidance of internationalism". (In Chen 2005, 41) That China regarded the Soviet Union as a competitor in its leadership of a communist "all-under-heaven" is clear from Mao Zedong's (1893-1976) aim to create a Chinese version of socialist internationalism after the country's break with the Soviet Union in 1959, as well as from the country's attempt to establish a united front of all anti-imperialist powers, starting in 1963. (See Chen 2005, 43) ${ }^{29}$

\section{Datong and New Confucianism}

With Confucianism being labeled as bourgeois and counter-revolutionary, Confucian scholars outside of mainland China further developed their interpretation of the datong concept and how it could be a guide for political action. According to Xiong Shili (1885-1968), China's backwardness that came visible in its nineteenth century confrontation with the West was the result of the fact that especially Neo-Confucianism of the Song and Ming dynasties had too much emphasized morality, and too little the "exploration of things" and the "extension of knowledge", the first two steps of the "eight steps" listed in the "Daxue". In the Song dynasty's systematization of Neo-Confucianism in its lixue form by Zhu $\mathrm{Xi}$, and in the Ming dynasty's systematization in its xinxue form by Wang Yangming (1472-1529), the focus had indeed been on the development of the moral self. The main difference between Zhu Xi's and Wang Yangming's interpretations was merely whether a human being's moral self had, in the process of physical creation, undergone a deterioration of its archetypical perfect form $(l i)$, and one thus had to strife to, through the study of the Confucian classics, reach the ultimate perfect morality, or, whether, as Wang Yangming claimed, human beings were perfect in themselves and had - through introspection - to find the ultimate morality in themselves. According to Xiong Shili, this attitude had prevented the development of scientific knowledge, in contrast to what the West had experienced. (Guo and Zhang 2001, 330; Rošker 2008, 226-7). He therefore advocated complementing the "Doctrine of the Inner Sage" (nei sheng) with the "Doctrine of the External Ruler" (wai wang). Such a renewed Confucianism would, according

29 See also Näth $(1975,259-68)$ for China's attempts to question the Soviet policies in Eastern Europe and in the international communist movement, and its attempts to isolate the Soviet Union wherever possible; and Näth (ibid., 284) for Zhou Enlai's focus on the conflict with the United States in the period 1968-1971. Especially after Nixon's visit to China in 1972, Chinese foreign policy was characterized by a fierce anti-Soviet stance (see ibid., 307). 
to him, lead to an "independent, free, equal, prosperous and democratic society of "great unity" (datong)". (Guo and Zhang 2001,330)

Tang Junyi (1909-1978), a Hong Kong-based New Confucian, made the important point that a datong society is not to be equated with a society of "sameness", by which he criticizes the Communist policies of the People's Republic of China. ${ }^{30}$ For this, he referred to the Lunyu, in which it is stated that "the nobleman creates harmony, not sameness; ordinary men, on the contrary, are all the same and cannot create harmony". (Lunyu, Zilu, 23) According to his political interpretation, this meant that only when China became a culture of harmony (bexie) would it be able to be the leader in the search for a perfect culture through integration with other cultures. (See Tang 2000, 293; Rošker 2016, 111)

\section{Datong and Contemporary New Confucianism in the People's Republic of China}

With the introduction of capitalist elements in its economy, the ascent of China in the contemporary world has increasingly put into question the communist aims of the ruling Communist Party. The parallel with the economic rise of the so-called four Asian economic tigers of which Singapore, Hong Kong and Taiwan were also the cradle of New Confucianism, has also led to the birth of a mainland Chinese New Confucianism. During the Hu Jintao era (China's State President from 2003 to 2013), the surprising introduction of Confucian concepts in CCP rhetoric especially highlighted the xiaokang concept. This focus may be related to the fact that the contemporary epoch of "socialism with Chinese characteristics" (you zhongguo tesede shehui zhuyi)—basically a form of state capitalism-leaves open the possibility that, in line with Marxist historiography, a communist datong society will be attained in the future. ${ }^{31}$ (Zlotea 2015, 157) In practical policies, achieving the xiaokang level is necessary in order to alleviate social and ethnic division, and hence keep the CCP in power. (Choukrone and Garaspane 2007, 30; Rošker 2016, 197) Achieving the xiaokang society will make it possible that, in an undefined future, the "harmonious society" (hexie shehui) can be achieved.

30 Note that Tang Junyi was born in mainland China, but went into exile in Hong Kong with the proclamation of the People's Republic of China in 1949.

31 Kou $(2012,51-55)$ also compared Confucian socialism to feudal socialism in the Communist Manifesto. He stated that while "Confucian socialism" was a utopian idea, socialism with Chinese characteristics was based on reality and deeply rooted in Chinese contemporary scientific socialism. Note also that Mao Zedong, in his Lun renmin minzhu zhuanzheng (On the Democratic Dictatorship of the People), described the attainment of a datong society as "a remote perspective of the progress of mankind". For the latter: see Bauer 1974, 544. 
The concept of the "harmonious society" has, as part of the Chinese dream of the Xi Jinping era, even been projected to become a "harmonious world" (hexie shijie).

It is therefore noteworthy that while the original forms of New Confucianism in Hong Kong and Taiwan emphasized the philosophy of Mengzi, mainland New Confucianism focuses on Xunzi who, being influenced by Legalist thinking, focused on the use of law. ${ }^{32}$ In the PRC, law is seen as an instrument to support the power of the CCP. This also explains the contemporary upsurge of guoxue departments (many PRC universities have established a guoxue yuan). Traditionally, guoxue studies were those Confucian studies that aimed at maintaining political power in the hands of the ruling imperial house. It is to this guoxue that early twentieth century junxue reacted in an attempt to restore the pre-imperial interpretation of Confucianism.

\section{Conclusion}

China's nineteenth century confrontation with a scientifically dominant West forced its intellectuals to rethink their traditional Confucian concepts. Convinced of the fact that China's backwardness was the outcome of the country's emphasis on morality, adopting Western rationality was seen as the solution to re-establishing the country on much stronger terms. The actual development of contemporary Chinese philosophy, however, shows the impossibility of ignoring the past and trying to start over with a tabula rasa past. ${ }^{33}$ (See Metzger 2012,228) Tu Weiming, a contemporary New Confucian thinker who, after an academic career in the US returned to Beijing University, expressed this as follows:

In both the Western and the non-Western worlds, the projected transition from tradition to modernity never occurred. As a norm, traditions continue in modernity. Indeed, the modernizing process itself is constantly shaped by a variety of cultural forms rooted in distinct traditions. ( $\mathrm{Tu} 2000,198$ )

32 Rošker (2016, 203-4) refers to Xunzi, Wang zhi 26 in this respect: "With the establishment of forms of punishment, the governing (of society) will become balanced and people will live in harmony", to which she remarks that the disciplinary connotation that prevailed in the understanding and propagation of a "harmonious society" in China under Hu Jintao, thus derives directly from Xunzi's interpretations of this notion.

33 Zhang Dainian (1909-2004) formulated this problem as follows: "Contemporary Chinese philosophy has to be connected to and be a continuation of the Chinese philosophy of the past. The kind of philosophy we need should not only be based on the most recent achievements of Western currents, but should first and foremost look at the authentic and original Chinese tradition". See Zhang 1984, Vol 1, 219. 


\section{References}

Bai, Tongdong. 2013. "An Old Mandate for a New State. On Jiang Qing's Political Confucianism.” In A Confucian Constitutional Order. How China's Ancient Past Can Shape Its Political Future, edited by Daniel A. Bell and Ruiping Fan, 113-28. Princeton and Oxford: Princeton University Press.

Bauer, Wolfgang. 1974. China und die Hoffnung auf Glück. Paradiese, Utopien, Idealvorstellungen in der Geistesgeschichte Chinas. München: DTV Wissenschaftliche Reihe.

Chan, Wing-tsit. 1963. A Source Book in Chinese Philosophy. Princeton: Princeton University Press.

Chen, Albert, H. Y. 2011. “The Concept of 'Datong' in Chinese Philosophy as an Expression of the Idea of the Common Good." Social Science Research Network. Legal Scholarship Network. Legal Studies Research Paper. University of Hong Kong Faculty of Law Research Paper No. 2011/20.

Chen, Weiping. 2014. "Lun Makesizhuyi yu Zhongguo chuantong wenhua xiangjiehede wu ge wenti 论马克思主义与中国传统文化相接和的五个问 题 (Five Questions on the Connection of Marxism with Chinese Traditional Culture)." Sixiang lilun jiaoyu 思想理论教育 (Ideological and Theoretical Education) 5: 4-8.

Chen, Zhimin. 2005. "Nationalism, Internationalism, and Chinese Foreign Policy." Journal of Contemporary China 14 (41): 35-53.

Choukrone, Leila, and Antoine Garapon. 2007. "The Norms of Chinese Harmony: Disciplinary Rules as Social Stabiliser.” China Perspectives 3: 36-49.

Cohen, Paul. 1997. History in Three Keys: The Boxers as Event, Experience and Myth. New York: Columbia University Press.

Dessein, Bart. 2016. "Historical Narrative, Remembrance, and the Ordering of the World. A Historical Assessment of China's International Relations.” In Cbina's International Roles. Challenging or supporting international order?, edited by Sebastian Harnisch, Sebastian Bersick, and Jörn-Carsten Gottwald, 22-37. Role Theory and International Relations. New York and London: Routledge.

—. Forthcoming. "Religion and the Nation: Confucian and New Confucian Religious Nationalism." In Religion and Nationalism in Chinese Societies, edited by Cheng-tian Kuo. Amsterdam: Amsterdam University Press.

Fairbank, John K. 1942. "Tributary Trade and China's Relations with the West." The Far Eastern Quarterly 1 (2): 129-49.

Fairbank, John K., and Su-yü Teng. 1941. "On the Ch'ing Tributary System.” Harvard Journal of Asiatic Studies 6 (1): 135-246.

Fei, Xiaotong. 1992. From the Soil. The Foundations of Chinese Society. Berkeley: University of California Press. 
Fitzgerald, John. 1996. Awakening China. Politics, Culture, and Class in the Nationalist Revolution. Stanford: Stanford University Press.

Goossaert, Vincent, and David A. Palmer. 2011. The Religious Question in Modern China. Chicago and London: The University of Chicago Press.

Guo, Yanwu, and Wenru Zhang. 2001. Zhongguo dangdai zhexue 中国当代哲学 (Contemporary Chinese Philosophy). Beijing: Beijing daxue chubanshe.

Harrison, Henrietta. 2001. China. Inventing the Nation. London: Arnold.

Hellendorff, Bruno. 2014. "Hiding behind the Tribute: Status, Symbol, and Power in Sino-Southeast Asian Relations, Past and Present.” In Interpreting China as a Regional and Global Power. Nationalism and Historical Consciousness in World Politics, Politics and Development of Contemporary China, edited by Bart Dessein. 142-68. Houndmills, Basingstoke: PalgraveMacmillan.

Hong, Xiuquan. 1961. “Taiping zhaoshu 太平詔書 (The Taiping Proclamation).” In Taiping tianguo yinshu 太平天國印書 (The Book of the Taiping Heavenly Kingdom), compiled by the Taiping Historical Museum. 20 vols. Nanjing: Jiangsu renmin chubanshe.

Jiang, Qing. 2013. A Confucian Constitutional Order. How China's Ancient Past Can Shape Its Political Future. Princeton and Oxford: Princeton University Press.

Kang, Youwei. 1936. Datong shu 大同书 (Book on the Great Unity). Shanghai: Zhonghua shuju.

—. 2002. Zhongguo zhexue shi 中国哲学史 (History of Chinese Philosophy), edited by Liu Wenying. Vol.1 and 2. Tianjin: Nankai daxue chubanshe.

Kou, Qingjie. 2012. "Buke jiang 'Rujia shehuizhuyi' yu Zhongguo tese shehuizhuyi xiangtibinglun. 不可讲“儒家社会主义’与中国特色社会主义相提并 论 (On the impossibility to mention Confucian Socialism and Socialism with Chinese Characteristics in One Breath).” Sixiang lilun jiaoyu daokan 思想理 论教育导刊 (Intellectual and Theoretical Education)12: 51-55.

Kuhn, Philip A. 1978. “The Taiping Rebellion.” In Cambridge History of China. Volume 10: Late Ch'ing 1800-1911. Part 1. Edited by John K. Fairbank, 264-317. Cambridge: Cambridge University Press.

Kuo, Ya-pei. 2008. "Redeploying Confucius: The Imperial State Dreams of the Nation (1902-1911)." In Chinese Religiosities: Affictions of Modernity and State Formation, edited by Mayfair Mei-hui Yang, 65-84. Berkeley and Los Angeles: University of California Press.

Legge, James. (1960) 1970. The She King or The Book of Poetry. The Chinese Classics. Hong Kong: Hong Kong University Press.

Li, Zehou. 1995. "Zai shuo xiti zhongyong - zai Guangzhou Zhongshan Daxue Xianggang Zhongwen Daxue Jiangyan 再说西体中用 - 在广州中山大学 
香港中文大学讲演 (Western substance and Chinese function - Lecture at Zhongshan University, Guangzhou; and Chinese University of Hong Kong). Accessed November 4, 2016. http://tieba.baidu.com/p/87024815.

Liji. 1988. In Si shu wu jing. Vol.2. Beijing: Zhongguo shudian.

Liu, Wuji, ed. 1953. "Introduction." In Readings in Contemporary Chinese Literature, 7-17. Far Eastern Publications. New Haven, Yale University Press.

Liu, Wenying. 2002. Zhongguo zhexue shi 中国哲学史 (A History of Chinese Philosophy). 2 vols. Tianjin: Nankai daxue chubanshe.

Lunyu. 1988. In Si shu wu jing. Vol.1. Beijing: Zhongguo shudian.

Mao, Zedong. 1961. Selected Works of Mao Zedong. Beijing: Foreign Languages Press. Volume 4. Accessed August 15, 2016. https://www.marxists.org/reference/archive/ mao/selected-works/volume-4/mswv4_65.htm.

Metzger, Thomas A. 2012. The Ivory Tower and the Marble Citadel. Essays on Political Philosophy in Our Modern Era of Interacting Cultures. Hong Kong: The Chinese University Press.

Näth, Marie-Luise. 1975. "Die Aussenpolitik der VR China: Talleyrand Redivivus?” In China nach der Kulturrevolution, edited by Jürgen Domes, 259-331. München: Wilhelm Finck Verlag.

Needham, Joseph. 1958. Science and Civilisation in China. Vol.2: History of Scientific Thought. Cambridge: Cambridge University Press.

Pusey, James Reeve. 1983. China and Charles Darwin. Harvard East Asian Monographs 100. Cambridge: Harvard University Press.

Rošker, Jana S. 2008. Searching for the Way. Theory of Knowledge in Pre-modern and Modern China. Hong Kong: The Chinese University Press.

- 2016. The Rebirth of the Moral Self. The Second Generation of Modern Confucians and their Modernization Discourses. Hong Kong: The Chinese University of Hong Kong.

Schmidt-Glintzer, Helwig. (2008) 2009. "Diagram (tu) and Text (wen): Mapping the Chinese World." In Conceiving the Empire. China and Rome Compared, edited by Fritz-Heiner Mutschler and Achim Mittag, 169-93. Oxford: Oxford University Press.

Schram, Stuart. 2002. “Mao Tse-Tung's Thought from 1949-1976.” In An Intellectual History of Modern China, edited by Merle Goldman and Leo Ou-fan Lee, 267-348. Cambridge: Cambridge University Press.

Schwartz, Benjamin I. 1985. The World of Thought in Ancient China. Cambridge and London: Harvard University Press.

Shun, Kwong-Loi. 2004. "Conception of the Person in Early Confucian Thought." In Confucian Ethics: A Comparative Study of Self, Autonomy, and Community, edited by Kwong-Loi Shun and David B. Wong, 183-99. Cambridge: Cambridge University Press. 
Sun, Zhongshan. 1960. Guofu Quanshu 國父全書 (Complete Works of the 'Father of the State'), edited by Hang Jiyun. Taipei: Dangshihui.

Tang, Junyi. 2000. Renwen jingshenzhi chongjian 人文精神之重建 (The Reconstruction of the Spirit of the Humanities). Taipei: Xuesheng shuju.

Tu, Weiming. 2000. "Implications on the Rise of 'Confucian' East Asia." Daedalus 129 (1): 195-219.

Wang, Edward Q. 2001. Inventing China Through History. The May Fourth Approach to Historiography. New York: State University of New York Press.

Wang, Tao. 1994. “Yuan dao 原道 (Explanation of the Dao)." In Dao yuan wenlu waibian. Vol.16. Edited by Zhang Dainian. Shenyang: Liaoning Renmin Chubanshe.

Wei, Yuan. 1852. Haiguo tuzhi 海國圖志 (Illustrated Treatise on the Countries in the Sea). Yangzhou.

Zhang, Dainian. 1984. Zhang Dainian wenji 张岱年文集 (A Collection of Essays by Zhang, Dainian). Beijing: Qinghua Daxue chubanshe.

Zhang, Qijun. 1988. Shudao yu datong 怒道與大同 (The Way of Forbearance and Datong). Taipei: Dongda.

Zhu, Xi. 1988. Daxue zhang ju ji zhu 大学章句及注 (The Words of the Chapter Great Learning and its Collected Commentaries). In Si shu wu jing. Vol.1. Beijing: Zhongguo shudian.

Zlotea, Mugur. 2015. "Weaving Confucianism into the Official Party Discourse: From Hu Jintao's 'Harmonious Society', to Xi Jinping's Communist junzi.” In Contemporary East Asia and the Confucian Revival, edited by Jana S. Rošker and Nataša Visočnik, 149-70. Newcastle upon Tyne: Cambridge Scholars Publishing. 